\title{
Giant panda reintroduction: factors affecting public support
}

\author{
Kai Ma' ${ }^{1}$ Dingzhen Liu' ${ }^{1} \cdot$ Rongping $\mathrm{Wei}^{2} \cdot$ Guiquan $\mathrm{Zhang}^{2} \cdot$ \\ Hao $\mathrm{Xie}^{2} \cdot$ Yan Huang ${ }^{2}$ Desheng $\mathrm{Li}^{2}$. Hemin Zhang ${ }^{2}$. \\ Haigen $\mathrm{Xu}^{3}$
}

Received: 22 October 2015/Revised: 1 September 2016/Accepted: 13 September 2016/ Published online: 21 September 2016

(C) The Author(s) 2016. This article is published with open access at Springerlink.com

\begin{abstract}
Reintroducing captive-born individuals of some extirpated flagship animal species is a helpful and remedy measure for promoting biodiversity conservation, and a successful reintroduction relies heavily on public support. However, little information is available on the factors affecting the public support for reintroduction of large carnivore species. In order to evaluate public support and willingness to pay for the Giant Panda Reintroduction Project (GPRP), we conducted 1100 interviews in August 2014 at Huaying city, Sichuan, China, close to where captive-born giant pandas (Ailuropoda melanoleuca) will be reintroduced. The results showed that local people strongly support this project and that $78.5 \%$ of them are willing to pay an annual contribution. Per capita annual payments averaged USD31, and the potential value of donations to the GPRP in Huaying is about 11 million USD per year. Factors like interviewees' residential area, occupation, education level, liking of wildlife, level of concern for wildlife conservation, the degree of familiarity with giant pandas, and the frequency of visiting captive giant pandas significantly affected their attitudes and willingness to pay for the project. The notion of "because I love pandas" was the main reason why respondents were willing to pay for the project; respondents' doubts about the appropriate use of donated funds made them be unwilling to pay for the
\end{abstract}

Communicated by Dirk Sven Schmeller.

Electronic supplementary material The online version of this article (doi:10.1007/s10531-016-1215-6) contains supplementary material, which is available to authorized users.

Dingzhen Liu

dzliu@bnu.edu.cn

1 Key Laboratory of Biodiversity Sciences and Ecological Engineering of Ministry of Education, College of Life Sciences, Beijing Normal University, Beijing 100875, P. R. China

2 Key Laboratory for Reproduction and Conservation Genetics of Endangered Wildlife of Sichuan Province, China Conservation and Research Center for the Giant Panda, Wolong 623006, Sichuan, P. R. China

3 Nanjing Institute of Environmental Sciences, Ministry of Environmental Protection, Nanjing 210042, P. R. China 
project. The results suggest that the GPRP is highly and socially acceptable amongst locals due to perceived social, economic and ecological benefits of the reintroduction. These findings clearly indicate, for the chances of reintroduction to be most socially accepted, governments should improve management and accountability when using donated funds, and create more opportunities for the public to engage with giant pandas, thereby encouraging people to become involved in conservation work benefiting conservation for the giant pandas and other endangered species.

Keywords Giant panda (Ailuropoda melanoleuca) - Release · Willingness to pay · Contingent valuation method · Conservation awareness · Questionnaire

\section{Introduction}

As a remedial measure preventing species from extinction, the reintroduction of extirpated threatened species is now well entrenched as a conservation tool (Bar-David et al. 2005). Since the very first reintroduction, in which 15 captive-bred American bison (Bison bison) were reintroduced into a newly established reserve in Oklahoma in 1907 (Kleiman 1989), more than 700 reintroduction projects have been implemented around the world (Seddon et al. 2012). Reviews of reintroduction projects have generally reported a low rate of success (less than $20 \%$; Osborne and Seddon 2012) and conservation biologists believe that a failure to properly consider the socioeconomic and political aspects of reintroductions may explain the predominance of poor outcomes (Arts et al. 2012; Bruskotter et al. 2010; Reading and Kellert 1993).

From a human dimension perspective, canvassing public opinion toward reintroduction programs is essential and prudent (Decker et al. 2010; Hermann et al. 2013; Worthington et al. 2010). Kleiman (1989) emphasized that a reintroduction cannot ultimately succeed without public support. Reintroductions, especially of large mammals, are generally controversial due to human-wildlife conflict resulting from herbivore damage to crops, carnivore attacks on livestock or humans, land-use changes and vehicle collisions (Lindsey et al. 2005; Nolet and Rosell 1998; Williams et al. 2002; Yen et al. 2015). Human-wildlife conflict often causes people to take a negative attitude toward reintroduced species and can greatly reduce the success rate of reintroduction projects (Campbell and Alvarado 2011; O'Rourke 2014; Wilson 2004). For example, a well-known failed reintroduction of eastern timber wolves (Canis lupes lycaen) in Michigan, USA during the 1970s involved all four wolves being killed because of strong opposition from livestock and hunting interests (Hook and Robinson 1982). More recently, the reintroduction of African wild dogs (Lycaon pictus) in Zimbabwe failed. The local people hunted and killed the reintroduced wild dogs because they believed those dogs would pose threats to livestock and children (Davies and du Toit 2004). In contrast, the acceptance of local residents toward a reintroduction project can greatly promote the project (Fischer and Lindenmayer 2000; Fritts et al. 1997; Kleiman et al. 1994; Osterberg et al. 2015). For example, in Argentina, the local community strongly supports the return of jaguars (Panthera onca) and human-jaguar conflict was well handled via ecotourism-mediated financial compensation schemes (Caruso and Perez 2013).

In addition to the public perception problem, reintroduction efforts are economically costly. For instance, it is estimated that the annual cost of the reintroduction of Californian condors (Gymnogyps californianus) is approximately one million US dollars (Cohn 1993) and the reintroduction of the gray wolf (Canis lupus) in North America costed USD 
6,700,000 over eight years (Bangs and Fritts 1996). Given the expense, it is essential that the public and local governments understand the benefits of reintroduction through a measurable and comparable index (money) so they can balance any contradiction between economic development and natural conservation (Kleiman 1989; Lindsey et al. 2005). The IUCN/SSC guidelines on species reintroduction suggest that potential economic value and payment capacity should be estimated for local communities, and especially where communities/regions are challenged economically (IUCN/SSC 2013). As a measure of valuing environmental public goods, the contingent valuation method (CVM) has been used to calculate public willingness to pay (WTP) for reintroduction projects (Han et al. 2010; Richardson and Loomis 2009; Su et al. 2008). The perceived economic value of reintroduction projects is considered to be a critical measure in determining the relative importance of these conservation efforts, and thus is necessary for prioritization (Lee et al. 2012; MacMillan et al. 2006).

In the feasibility evaluation of reintroduction projects from a human perspective, a generalized paradigm including socioeconomic variables (Morzillo et al. 2010; Reading et al. 1991) and affective (emotional) variables (Jacobs et al. 2014; Lindon and RootBernstein 2015) has been developed. For socioeconomic variables, Williams et al. (2002) summarized 109 reports of public attitudes toward the reintroduction of wolves from 1972 to 2000. Public attitudes toward wolves are associated with residential area, gender, age, occupation, education level and monthly income. For affective variables, important factors influencing attitudes toward wildlife include species characteristics (phylogeny, morphology, size and sentient capacity) and the perceived worth of the animal (aesthetic, ethical, recreational and cultural) (Kellert 1984; Kellert and Berry 1980; Reading and Kellert 1993). The characteristics of a species directly influence human feelings, thus "liking of wildlife" is a general measure of public attitude towards nature conservation (Mayer and Frantz 2004; Nisbet et al. 2009; Perkins 2010). The perceived worth of a species is closely associated with cognitive and affective components. Those components are often influenced by knowledge of the species (degree of familiarity with the species), moral and ethical issues of animal rights (level of concern for wildlife conservation), and experiences with the species (frequency of encountering the species in the wild or visiting captive animals) (Heberlein 2012; Knegtering et al. 2002; Tisdell et al. 2007; Zhang et al. 2014a).

Assessing the practicability of reintroduction programs is a site-specific and speciesspecific task (Arts et al. 2012; Ericsson and Heberlein 2003; Tosi et al. 2015). To our knowledge, little has been done on WTP and public attitudes towards the reintroduction of large and endangered mammals in China despite the government plans for reintroduction programs in the giant panda (Ailuropoda melanoleuca), Chinese water deer (Hydropotes inermis), Père David's deer (Elaphurus davidianus) and Przewalski's wild horse (Equus ferus przewalskii). In this study, we used the iconic, flagship species of giant panda to investigate the effects of socioeconomic background and personal feelings of support for its reintroduction in Huaying, Sichuan, China.

The giant panda is an endangered and umbrella species in China, and is considered a necessary instrument for the conservation of nature (Kontoleon and Swanson 2003). Since the establishment of the first nature reserve for the giant panda (Wolong National Nature Reserve) in 1963, Chinese government has established 67 nature reserves aiming for panda conservation, with a total area of 3.36 million $\mathrm{hm}^{2}$ (State Forestry Administration 2014). Many sympatric endemic and endangered species such as snub-nosed monkeys (Rhinopithecus roxellarae), takins (Budorcas taxicolor), red pandas (Ailurus fulgens), snow leopards (Panthera uncia), and Chinese giant salamanders (Andrias davidianus), are also 
protected in those panda reserves. Moreover, the giant panda has a very high aesthetic, scientific and ecological value. It has attracted immense financial and human resources and international attention (Loucks et al. 2001; Li et al. 2010).

The 1800 remaining wild giant pandas are fragmented across 33 small local populations by natural isolation and human disturbance (State Forestry Administration 2014). Wild populations remain under pressure due to habitat fragmentation and demographic isolation, and some are at risk of extinction (Wei et al. 2012). In order to supplement and reinforce extant populations, scientists have been working on translocating rescued wild giant pandas into reserves and releasing captive-born individuals into the wild. Plans are also underway to reintroduce captive-born pandas into areas previously inhabited by giant pandas. Huaying Mountain has been selected as a target area for the first reintroduction of giant pandas (Zhang et al. 2014b); however, the attitudes of local residents to this reintroduction and the potential economic support of the project remain unknown.

We conducted a survey to investigate the public opinions on the Giant Panda Reintroduction Project (GPRP) in Huaying area prior to implementing this reintroduction. Our aims were to (1) determine the level of public support and WTP towards the GPRP; (2) understand the underlying reasons of public support and WTP towards the GPRP; and (3) explain public support and WTP using socioeconomic variables (residential area, gender, age, occupation, education level, and monthly income) and affective variables (liking of wildlife, level of concern for wildlife conservation, degree of familiarity with giant pandas, and frequency of visiting captive giant pandas). Given the importance of public engagement and support in the success of species reintroductions, our results will guide the ex situ conservation of giant pandas and inform future critical decision-making by governments and non-governmental protection organizations.

\section{Materials and methods}

\section{Study area}

The survey was conducted using face-to-face interviews from 3 to 28 August 2014 at Huaying City $\left(30^{\circ} 23^{\prime} \mathrm{N}, 106^{\circ} 46^{\prime} \mathrm{E}\right)$, Sichuan in Southwest China. Huaying is a small city with a population of 362,000 and a total area of $466 \mathrm{~km}^{2}$. In 2013, the general financial revenue of the local government was 388 million Chinese Yuan (USD63 million; during the field survey period, USD1 $=$ CNY6.15), the per capita disposable income of urban households was CNY21,865 (USD3,555), the per capita net income of rural households was CNY9,591 (USD1,560), and the annual per capita living expenses of rural residents was CNY3,150 (USD512). The survey sites include urban and rural areas adjacent to the proposed reintroduction site for giant pandas.

\section{Survey sample size determination}

We adopted random sampling when interviewing local residents. We used Scheaffer's formula to estimate the required sample size (Scheaffer et al. 2011):

$$
n=\frac{N}{(N-1) \delta^{2}+1}
$$


where $n$ is the sample size; $N$ is the number of people in the sampled population; and $\delta$ is acceptable sampling error (generally $5 \%$ ). Thus, according to the total population of the survey area, the sample size should be greater than or equal to 400 .

The likely effective response rate for the questionnaire was also taken into consideration in order to calculate the sample size. In other similar studies in China, the effective response rate for interview questionnaires on wildlife and biodiversity is usually greater than $80 \%$ (Pan et al. 2010; Hu et al. 2013). Therefore, the actual sample size should not be less than 500. However, Mitchell and Carson (1989) point out sample sizes based on the CVM should be greater than the general statistical threshold. And the US National Oceanic and Atmospheric Administration (NOAA) suggests that sample sizes should preferably be greater than 1000 (Arrow et al. 1993). Consequently, a total of 1100 questionnaires were issued and all were returned (response rate $100 \%$ ). After excluding incomplete and casually written questionnaires, 1011 questionnaires were valid and used for analysis (effective response rate $92 \%$ ), a large enough sample size providing sufficient statistical power.

For the high positive response rate in our current study, we thought it might be a cultural issue. The giant panda has long been regarded as a source of pride in China. This is particularly true for local communities in Sichuan province, and they have benefited much from the panda culture. All activities concerning with giant pandas will be warmly welcomed and supported by local community. A previous literature shows that Huaying mountain area used to be a historical distribution area of the giant panda (Chu and Long 1983), and one fossil of the giant panda (A. m. baconi) was later found in Huaying mountain area in 1993 (Hu et al. 1995). The GPRP was initially proposed by the State Forestry Administration for the aim to promote the wild panda population recovery in Sichuan province. It will be supervised by the Department of Forestry of Sichuan province, and conducted by China Conservation and Research Center for the giant panda at Wolong. Supports in economy and policy from both the state, province, local government and conservation institutions gave the local people big hopes and confidences for the success of this planned project.

\section{Questionnaire design}

According to design principles for CVM questionnaires proposed by NOAA, and similar studies (Mitchell and Carson 1989; Arrow et al. 1993; Turpie 2003; MacMillan et al. 2006; Nuva et al. 2009), we used a payment scale question to assess WTP towards the GPRP. In accordance with the results of a preliminary survey (Zhang et al. 2014b), and using feedback from our previous open questionnaire during the pilot survey, we determined bid amounts, questions and options. All questions were multiple choices: 17 of them required a single answer and three were multiple response questions. The questionnaire has a high internal consistency and structure validity (Cronbach $\alpha=0.801$; Kaiser-Meyer-Olkin value $=0.736$; Bartlett's Test of Sphericity: approximate $\chi^{2}=2066.452, d f=10, P=0.000$ ).

The final formal questionnaire was divided into six sections (see Supplementary material 1): (1) the cover provided the requirements and purposes of the survey, and introduction to the GPRP. (2) Respondents' socio-demographics. We designated the respondents' residential area as two choices (rural or urban) in the questionnaire form. There were six groups for respondents' age, eight groups for occupation, five groups for education levels, and ten groups for monthly income. (3) Respondents' prior-experience about wildlife and giant pandas. (4) Respondents' level of support and motivations towards the GPRP. (5) Respondents' WTP and motivations towards the GPRP. Both the respondents' prior experiences and degree of support were ranked on a five-point Likert scale 
with corresponding scores: very negative, negative, neutral, positive and very positive. (6) A reminder to check that all questions have been answered and a note of thanks for the respondent. It is worth mentioning that two common-sense questions were included in the sections of 3 and 4 of the questionnaire form in order to identify invalid questionnaires. The questionnaire forms would be excluded in subsequent statistical analyses if the respondent answered either one of the two common-sense questions incorrectly. We thought that the survey might not have been taken seriously, or the respondent's knowledge about the giant panda and conservation was not qualified for taking the survey.

\section{Interview method}

In rural areas with sparse populations we performed door-to-door interviews. For each household only one family member was randomly selected by drawing lots to participate in the questionnaire. The survey sites covered seven villages/towns surrounding Huaying Mountain area. In urban areas with dense populations we performed individual interviews. Survey sites were chosen in public places, such as banks, supermarkets, parks, vocational-technical schools, carnivals, government offices and company offices, where people could be randomly found. Ten trained and experienced interviewers conducted the surveys. The interviewer training method referenced a general personal interview protocol for questionnaires (Scheaffer et al. 2011). Interviewers were chosen from Huaying City and were familiar with the urban layout, traffic and local dialect. They were all required to keep a neutral attitude and to state objective facts pre-, during and post- the survey. The interviewers usually emphasized that there were no right or wrong answers to the questions in the survey but simply to seek opinion. They distributed small gifts to respondents in return for participation in the survey. All respondents were asked to complete the questionnaire independently at the site of the interview.

\section{Statistical analysis}

For all questionnaire forms collected, we first identified their validity by examining the answers to the two common-sense questions in addition to examining answers to other questions and requirements for each questions. Then, we input the data from all valid questionnaire forms into Excel. Next, we recoded the respondents' answers to questions about their prior experiences and degree of support as corresponding scores: very negative $(-2)$, negative $(-1)$, neutral $(0)$, positive (1) and very positive (2) according to five-point Likert scale. For the simplicity and convenience of data analysis, we combined and defined the age group from six to four, occupation group from eight to seven, education level from five to two, and monthly income group from ten to three (Table 1). The category and data of highly negative supporting degree to the GPRP was excluded in the subsequent analysis due to the fact that all were zero values.

According to the probability distribution of WTP, the arithmetic mean of WTP was calculated by the mathematical expectation formula of discrete variables (Voltaire et al. 2013; You et al. 2014).

$$
E(W T P>0)=\sum_{i=1}^{n} B_{i} P_{i}
$$

where $E(W T P>0)$ represents the average of the positive WTP; $B_{i}$ is the bid amount of WTP; $P_{i}$ is the probability that each bid value was chosen by respondents; and $n$ is the number of bid amount. 
Table 1 Summary of socioeconomic profiles of respondents and their attitudes to the giant panda reintroduction project

\begin{tabular}{|c|c|c|c|c|c|c|}
\hline \multirow[t]{2}{*}{ Variables } & \multirow[t]{2}{*}{ Categories } & \multicolumn{4}{|c|}{ Number of individuals ${ }^{\mathrm{a}}$} & \multirow[t]{2}{*}{ Sum } \\
\hline & & $\begin{array}{l}\text { Strongly } \\
\text { support }\end{array}$ & Support & Neutral & Oppose & \\
\hline \multirow[t]{2}{*}{ Residential area } & Urban & 406 & 167 & 34 & 0 & 607 \\
\hline & Rural & 219 & 144 & 40 & 1 & 404 \\
\hline \multirow[t]{2}{*}{ Gender } & Male & 311 & 153 & 41 & 0 & 505 \\
\hline & Female & 314 & 158 & 33 & 1 & 506 \\
\hline \multirow[t]{4}{*}{$\mathrm{Age}^{\mathrm{b}}$} & Youth & 52 & 18 & 5 & 0 & 75 \\
\hline & Young adult & 213 & 121 & 28 & 1 & 363 \\
\hline & Midlife & 289 & 134 & 30 & 0 & 453 \\
\hline & Older & 71 & 38 & 11 & 0 & 120 \\
\hline \multirow[t]{7}{*}{ Occupation $^{\mathrm{c}}$} & $\begin{array}{l}\text { Civil servant/ } \\
\text { Government official }\end{array}$ & 161 & 49 & 8 & 0 & 218 \\
\hline & Public service worker & 138 & 51 & 14 & 0 & 203 \\
\hline & $\begin{array}{l}\text { State-own Company } \\
\text { employee }\end{array}$ & 77 & 27 & 8 & 0 & 112 \\
\hline & Self-employed & 70 & 48 & 12 & 0 & 130 \\
\hline & Farmer & 93 & 83 & 24 & 1 & 201 \\
\hline & Student & 74 & 40 & 6 & 0 & 120 \\
\hline & Pensioner & 12 & 13 & 2 & 0 & 27 \\
\hline \multirow[t]{2}{*}{ Education level $^{\mathrm{d}}$} & High school or below & 356 & 157 & 31 & 0 & 544 \\
\hline & College or above & 269 & 154 & 43 & 1 & 467 \\
\hline \multirow[t]{3}{*}{ Monthly income $e^{e}$} & Low income & 134 & 77 & 12 & 1 & 224 \\
\hline & Middle income & 450 & 213 & 56 & 0 & 719 \\
\hline & High income & 41 & 21 & 6 & 0 & 68 \\
\hline \multirow[t]{5}{*}{ Liking of wildlife } & I like it very much & 388 & 61 & 8 & 0 & 457 \\
\hline & I like it & 195 & 133 & 11 & 0 & 339 \\
\hline & I like it moderately & 41 & 113 & 47 & 1 & 202 \\
\hline & I dislike it & 1 & 4 & 8 & 0 & 13 \\
\hline & I dislike it very much & 0 & 0 & 0 & 0 & 0 \\
\hline \multirow{5}{*}{$\begin{array}{l}\text { Level of concern for } \\
\text { wildlife } \\
\text { conservation }\end{array}$} & Very concerned & 338 & 45 & 3 & 0 & 386 \\
\hline & Concerned & 218 & 139 & 6 & 1 & 364 \\
\hline & Moderately concerned & 62 & 108 & 46 & 0 & 216 \\
\hline & A little concerned & 7 & 18 & 18 & 0 & 43 \\
\hline & Not concerned at all & 0 & 1 & 1 & 0 & 2 \\
\hline \multirow{5}{*}{$\begin{array}{l}\text { Degree of familiarity } \\
\text { with giant pandas }\end{array}$} & Very familiar & 144 & 21 & 1 & 0 & 166 \\
\hline & Familiar & 183 & 104 & 8 & 0 & 295 \\
\hline & Moderately familiar & 216 & 135 & 38 & 0 & 389 \\
\hline & A little familiar & 79 & 48 & 26 & 1 & 154 \\
\hline & Unfamiliar & 3 & 3 & 1 & 0 & 7 \\
\hline
\end{tabular}


Table 1 continued

\begin{tabular}{|c|c|c|c|c|c|c|}
\hline \multirow[t]{2}{*}{ Variables } & \multirow[t]{2}{*}{ Categories } & \multicolumn{4}{|c|}{ Number of individuals ${ }^{\mathrm{a}}$} & \multirow[t]{2}{*}{ Sum } \\
\hline & & $\begin{array}{l}\text { Strongly } \\
\text { support }\end{array}$ & Support & Neutral & Oppose & \\
\hline \multirow{5}{*}{$\begin{array}{l}\text { Frequency of visiting } \\
\text { captive giant pandas }\end{array}$} & Very frequently & 103 & 12 & 3 & 0 & 118 \\
\hline & Frequently & 93 & 69 & 2 & 0 & 164 \\
\hline & Moderately Frequently & 190 & 115 & 35 & 0 & 340 \\
\hline & Occasionally & 161 & 71 & 23 & 1 & 256 \\
\hline & Never & 78 & 44 & 11 & 0 & 133 \\
\hline
\end{tabular}

a The category and data for 'highly oppose' were omitted due to all zero values

b Age groups were reclassified as: youth $(\leq 18)$, young adult (19-29), midlife (30-49), older $(\geq 50)$ in the data analysis

c Respondents occupation as "soldier" was incorporated into "public service worker"

d Education level was reclassified as high school or below and college or above

e Monthly income was reclassified as low income ( $\leq 1000 \mathrm{CNY})$, middle income (1000-4000CNY), high income $(\geq 4000 \mathrm{CNY})$

Considering the existence of partial zero WTP, the Spike model was applied (Kriström 1997; Reiser and Shechter 1999).

$$
\begin{gathered}
E(W T P)=E(W T P>0) * P \\
V_{T}=E(W T P) * T
\end{gathered}
$$

where $E(W T P)$ represents the non-negative WTP; $P$ is the probability of nonzero payment; $T$ is the total population number of sampled area; and $V_{T}$ is the total WTP in the sampled area with $T$ individuals.

We used Mann-Whitney $U$ test or Kruskal-Wallis one-way ANOVA to analyze the difference in public supporting degree to the GPRP between respondents in two residential areas, two genders, and two education levels, or among respondents in four age groups, seven occupations, and three monthly income groups. We further used Cross-table tests to analyze the differences in frequency distribution in four supporting degrees by socioeconomic factors and five personal experience levels. We used Spearman rank correlation test to analyze the relationships between public supporting degree and personal prior experience. Logistic regression modeling was used to analyze WTP towards the GPRP and socioeconomic factors and personal prior experiences. Chi square goodness-of-fit tests were used to analyze single-answer questions. The multiple dichotomy method was used to analyze multiple-answer questions. All statistical analyses were conducted using SPSS 17.0 for Windows (SPSS Inc., Chicago, USA). Alpha was set at 0.05 and all tests were two-tailed.

\section{Results}

\section{Sample characteristics}

We totally identified 1011 valid questionnaire forms. The ratio of respondents living in urban and rural areas was $1.5: 1$; the sex ratio was $1: 1$; respondents were mainly 
19-49 years old (age categories young adult and midlife); most worked as civil servants/government officials in government agencies, in public services and in farms (Table 1; Supplementary material 2). The education level of respondents was mostly high school or below, the second most common sub-category was junior college and university degree, and less than $3 \%$ of respondents had higher degrees. The majority of respondents had a monthly income of below CNY4,000 (USD650), and respondents with monthly income below CNY1,000 (USD163) were mainly pensioners and students. Students' incomes (namely costs) were mainly subsistence and pocket money from parents and schools. In addition, respondents generally liked wildlife and had a high level of concern for wildlife conservation. Those respondents with a moderate/or below degree of familiarity with or frequency of visiting captive pandas showed a high ratio of neutral supporting degree to the GPRP (Table 1; Supplementary material 3).

\section{Public attitudes to the GPRP and associated factors}

Respondents had a very positive attitude toward the GPRP. More than $90 \%$ of people expressed support for the project: $61.8 \%$ of respondents were strongly supportive, $30.8 \%$ of people were supportive, $7.3 \%$ of people remained neutral, and only one person $(0.1 \%)$ did not support this project. The percentage of opposition was too small to be reported.

Respondents thought that the GPRP would have some positive (or negative) impact on Huaying city. Of respondents, $74.6 \%$ believed that the project would improve the popularity of Huaying; $64.7 \%$ thought it would attract more tourists, thereby increasing local revenue; $51.0 \%$ thought it would improve the ecological environment; $47.9 \%$ thought it would raise public awareness of environmental protection; $32.3 \%$ thought it would increase opportunities for employment; and $5.6 \%$ questioned that it would damage the interests of villagers in and neighboring Huaying Mountain.

Urban residents were more supportive than rural residents to the GPRP (Table 2). Of all occupations, civil servants/government officials had the most positive attitude of supporting ratio; the second most positive group consisted of state-own company employees, public service workers, and students; the third positive group was self-employed people; and the least positive groups were farmers and pensioners. Statistic results showed that civil servants/government officials, state-own company employees and public service workers had significantly higher degree of supporting than other four occupations except students (Table 2; Supplementary material 4). People with higher education levels tended to be more supportive to the project than those with high school or below education level. The respondents' prior experiences, such as "liking of wildlife", "level of concern for wildlife conservation", "degree of familiarity with giant pandas", and "frequency of visiting captive giant pandas", were all positively and significantly correlated with levels of support for the GPRP.

\section{Willingness to pay for the GPRP and associated factors}

More than three quarters of respondents $(78.5 \%)$ were willing to pay an annual contribution towards the GPRP; 217 (21.5\%) people were unwilling to pay. Of respondents who were willing to pay, $83.2 \%$ said they would pay CNY200 (USD33) or less for the GPRP annually (Fig. 1). On the basis of the frequency distribution of bids, the per capita annual payments can be calculated as following: 
Table 2 Public attitudes and supporting degree towards the Giant Panda Reintroduction Project and statistic results

\begin{tabular}{|c|c|c|c|c|c|c|c|}
\hline \multirow[t]{2}{*}{ Variables } & \multirow[t]{2}{*}{ Categories } & \multirow{2}{*}{$\begin{array}{l}\text { Differences } \\
\text { in degree of } \\
\text { supporting }\end{array}$} & \multicolumn{4}{|c|}{ Percentage of different attitudes $(\%)$} & \multirow{2}{*}{$\begin{array}{l}\text { Cross-table } \\
\text { analysis }\end{array}$} \\
\hline & & & $\begin{array}{l}\text { Strongly } \\
\text { support }\end{array}$ & Support & Neutral & Oppose $^{\mathrm{s}}$ & \\
\hline \multirow{2}{*}{$\begin{array}{l}\text { Residential } \\
\text { area }\end{array}$} & Urban & $Z=-4.24^{\mathrm{a}}$ & 66.9 & 27.5 & 5.6 & 0.0 & \multirow{2}{*}{$\begin{array}{l}X^{2}=18.28 \\
P=0.001 \\
d f=2\end{array}$} \\
\hline & Rural & $P=0.0001$ & 54.2 & 35.6 & 9.9 & 0.2 & \\
\hline \multirow[t]{2}{*}{ Gender } & Male & $Z=-0.31^{\mathrm{a}}$ & 61.6 & 30.3 & 8.1 & 0.0 & \multirow{2}{*}{$\begin{array}{l}X^{2}=0.747 \\
P=0.688 \\
d f=2\end{array}$} \\
\hline & Female & $P=0.759$ & 62.1 & 31.2 & 6.5 & 0.2 & \\
\hline \multirow[t]{4}{*}{ Age } & Youth & $X^{2}=4.39^{b}$ & 69.3 & 24.0 & 6.7 & 0.0 & \multirow{4}{*}{$\begin{array}{l}X^{2}=4.80 \\
P=0.570 \\
d f=4\end{array}$} \\
\hline & Young adult & $P=0.222$ & 58.7 & 33.3 & 7.7 & 0.3 & \\
\hline & Midlife & & 63.8 & 29.6 & 6.6 & 0.0 & \\
\hline & Older & & 59.2 & 31.7 & 9.2 & 0.0 & \\
\hline \multirow[t]{7}{*}{ Occupation } & $\begin{array}{l}\text { Civil servant/ } \\
\text { Government } \\
\text { official }\end{array}$ & $\begin{array}{l}X^{2}=47.15^{\mathrm{b}} \\
P=0.0001\end{array}$ & 73.9 & 22.5 & 3.7 & 0.0 & \multirow[t]{7}{*}{$\begin{array}{l}X^{2}=50.64 \\
P=0.001 \\
d f=12\end{array}$} \\
\hline & $\begin{array}{l}\text { Public service } \\
\text { worker }\end{array}$ & & 68.0 & 25.1 & 6.9 & 0.0 & \\
\hline & $\begin{array}{l}\text { State-own } \\
\text { company } \\
\text { employee }\end{array}$ & & 68.8 & 24.1 & 7.1 & 0.0 & \\
\hline & Self-employed & & 53.8 & 36.9 & 9.2 & 0.0 & \\
\hline & Farmer & & 46.3 & 41.3 & 11.9 & 0.5 & \\
\hline & Student & & 61.7 & 33.3 & 5.0 & 0.0 & \\
\hline & Pensioner & & 44.4 & 48.1 & 7.4 & 0.0 & \\
\hline \multirow[t]{2}{*}{$\begin{array}{l}\text { Education } \\
\text { level }\end{array}$} & $\begin{array}{l}\text { High school or } \\
\text { below }\end{array}$ & $\begin{array}{l}Z=-2.78^{\mathrm{a}} \\
P=0.005\end{array}$ & 57.6 & 33.0 & 9.2 & 0.2 & \multirow{2}{*}{$\begin{array}{l}X^{2}=8.11 \\
P=0.017 \\
d f=2\end{array}$} \\
\hline & $\begin{array}{l}\text { College or } \\
\text { above }\end{array}$ & & 65.4 & 28.9 & 5.7 & 0.0 & \\
\hline \multirow{3}{*}{$\begin{array}{l}\text { Monthly } \\
\text { income }\end{array}$} & Low income & $X^{2}=0.35^{\mathrm{b}}$ & 59.8 & 34.4 & 5.4 & 0.4 & \multirow{3}{*}{$\begin{array}{l}X^{2}=3.10 \\
P=0.541 \\
d f=4\end{array}$} \\
\hline & Middle income & $P=0.841$ & 62.6 & 29.6 & 7.8 & 0.0 & \\
\hline & High income & & 60.3 & 30.9 & 8.8 & 0.0 & \\
\hline \multirow[t]{5}{*}{$\begin{array}{r}\text { Liking of } \\
\text { wildlife }\end{array}$} & $\begin{array}{l}\text { I like it very } \\
\text { much }\end{array}$ & $\begin{array}{l}r=0.522^{\mathrm{c}} \\
P=0.0001\end{array}$ & 84.9 & 13.3 & 1.8 & 0.0 & \multirow{5}{*}{$\begin{array}{l}X^{2}=349.30 \\
P=0.0001 \\
d f=6\end{array}$} \\
\hline & I like it & $n=1011$ & 57.5 & 39.2 & 3.2 & 0.0 & \\
\hline & $\begin{array}{l}\text { I like it } \\
\text { moderately }\end{array}$ & & 20.3 & 55.9 & 23.3 & 0.5 & \\
\hline & I dislike it & & 7.7 & 30.8 & 61.5 & 0.0 & \\
\hline & $\begin{array}{l}\text { I dislike it very } \\
\text { much }\end{array}$ & & 0.0 & 0.0 & 0.0 & 0.0 & \\
\hline \multirow{4}{*}{$\begin{array}{l}\text { Level of } \\
\text { concern for } \\
\text { wildlife } \\
\text { conservation }\end{array}$} & $\begin{array}{l}\text { Very } \\
\text { concerned }\end{array}$ & $\begin{array}{l}r=0.518^{\mathrm{c}} \\
P=0.0001\end{array}$ & 87.6 & 11.7 & 0.8 & 0.0 & \multirow{4}{*}{$\begin{array}{l}X^{2}=343.05 \\
P=0.001 \\
d f=6\end{array}$} \\
\hline & Concerned & $n=1011$ & 59.9 & 38.2 & 1.6 & 0.3 & \\
\hline & $\begin{array}{l}\text { Moderately } \\
\text { concerned }\end{array}$ & & 28.7 & 50.0 & 21.3 & 0.0 & \\
\hline & $\begin{array}{l}\text { A little } \\
\text { concerned }\end{array}$ & & 15.6 & 42.2 & 42.2 & 0.0 & \\
\hline
\end{tabular}


Table 2 continued

\begin{tabular}{|c|c|c|c|c|c|c|c|}
\hline \multirow[t]{2}{*}{ Variables } & \multirow[t]{2}{*}{ Categories } & \multirow{2}{*}{$\begin{array}{l}\text { Differences } \\
\text { in degree of } \\
\text { supporting }\end{array}$} & \multicolumn{4}{|c|}{ Percentage of different attitudes (\%) } & \multirow{2}{*}{$\begin{array}{l}\text { Cross-table } \\
\text { analysis }\end{array}$} \\
\hline & & & $\begin{array}{l}\text { Strongly } \\
\text { support }\end{array}$ & Support & Neutral & Oppose $^{\mathrm{s}}$ & \\
\hline & $\begin{array}{l}\text { Not concern at } \\
\text { all }\end{array}$ & & 0.0 & 50.0 & 50.0 & 0.0 & \\
\hline \multirow{5}{*}{$\begin{array}{l}\text { Degree of } \\
\text { familiarity } \\
\text { with giant } \\
\text { pandas }\end{array}$} & Very familiar & $r=0.234^{\mathrm{c}}$ & 86.7 & 12.7 & 0.6 & 0.0 & \multirow{5}{*}{$\begin{array}{l}X^{2}=87.60 \\
P=0.0001 \\
d f=6\end{array}$} \\
\hline & Familiar & $P=0.0001$, & 62.0 & 35.3 & 2.7 & 0.0 & \\
\hline & $\begin{array}{l}\text { Moderately } \\
\text { familiar }\end{array}$ & & 55.5 & 34.7 & 9.8 & 0.0 & \\
\hline & $\begin{array}{l}\text { A little } \\
\text { familiar }\end{array}$ & & 51.3 & 31.2 & 16.9 & 0.6 & \\
\hline & Unfamiliar & & 42.9 & 42.9 & 14.3 & 0.0 & \\
\hline \multirow{5}{*}{$\begin{array}{l}\text { Frequency of } \\
\text { visiting } \\
\text { captive giant } \\
\text { pandas }\end{array}$} & $\begin{array}{l}\text { Very } \\
\text { frequently }\end{array}$ & $\begin{array}{l}r=0.09^{c} \\
P=0.004\end{array}$ & 87.3 & 10.2 & 2.5 & 0.0 & \multirow{5}{*}{$\begin{array}{l}X^{2}=57.92, \\
P=0.0001, \\
d f=8\end{array}$} \\
\hline & Frequently & $n=1011$ & 56.7 & 42.1 & 1.2 & 0.0 & \\
\hline & $\begin{array}{l}\text { Moderately } \\
\text { Frequently }\end{array}$ & & 55.9 & 33.8 & 10.3 & 0.0 & \\
\hline & Occasionally & & 62.9 & 27.7 & 9.0 & 0.4 & \\
\hline & Never & & 58.6 & 33.1 & 8.3 & 0.0 & \\
\hline
\end{tabular}

\footnotetext{
s- The percentage data of "strongly opposed" were omitted due to all zero values for this variable

a Mann-Whitney $U$ test

b Kruskal-Wallis one-way Anova

c Spearman Rank Correlation test
}

$$
\begin{gathered}
E(W T P>0)=\sum_{i=1}^{11} B_{i} P_{i}=239.32 \\
E(W T P)=E(W T P>0) * P=239.2 * 78.5 \%=187.87
\end{gathered}
$$

This means that the expected value of willingness to pay is about CNY 188 (USD31). Consequently, $V_{T}=E(W T P) * T=187.87 \times 361995.00=680.08 \times 10^{5}$, which means the potential economic value of donations to the GPRP in Huaying is about 68 million Chinese Yuan (11 million US dollars) per year.

Among the respondents, young people (age $\leq 29$ ), and those having higher education degrees (college or above) or living in urban area, and civil servant/government official/ public service workers were the major groups of WTP to support the GPRP (Fig. 2). Respondents' "liking of wildlife", "level of concern for wildlife conservation", "degree of familiarity with giant pandas", and "frequency of visiting captive giant pandas" were positively correlated with WTP.

\section{Reasons for being willing or unwilling to pay}

The main reasons people were WTP included: "because I love pandas" (56.1\% of willing respondents); "the giant panda is a national treasure" (55.0\%); "for the conservation of the giant panda, to make its distribution more widespread and to increase population 


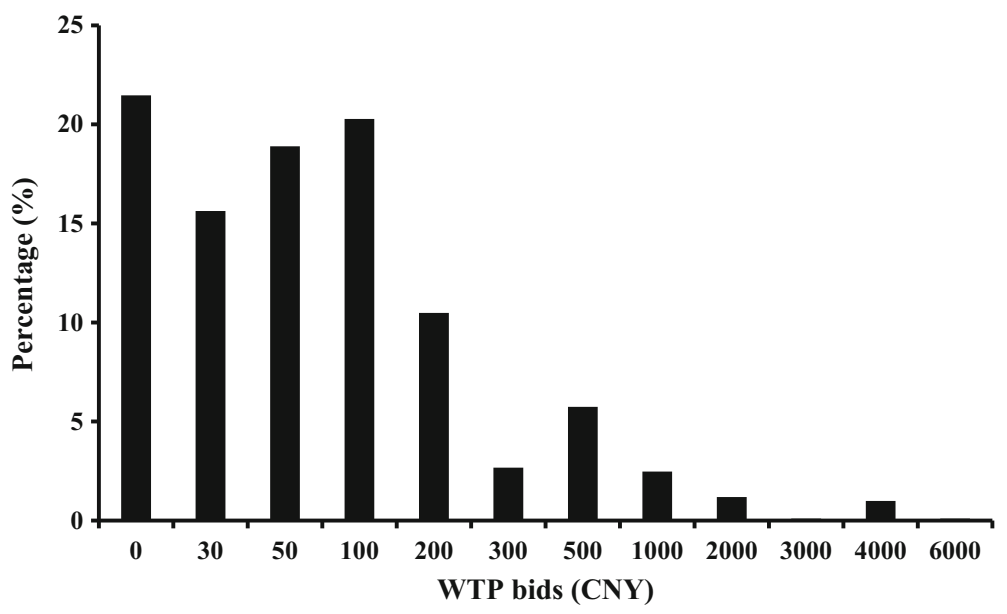

Fig. 1 The distribution of respondents' willingness-to-pay (WTP) bids, in Chinese Yuan (CNY). Percentages were calculated based on all respondents; 'zero' bar shows the percentage of people who were unwilling to pay

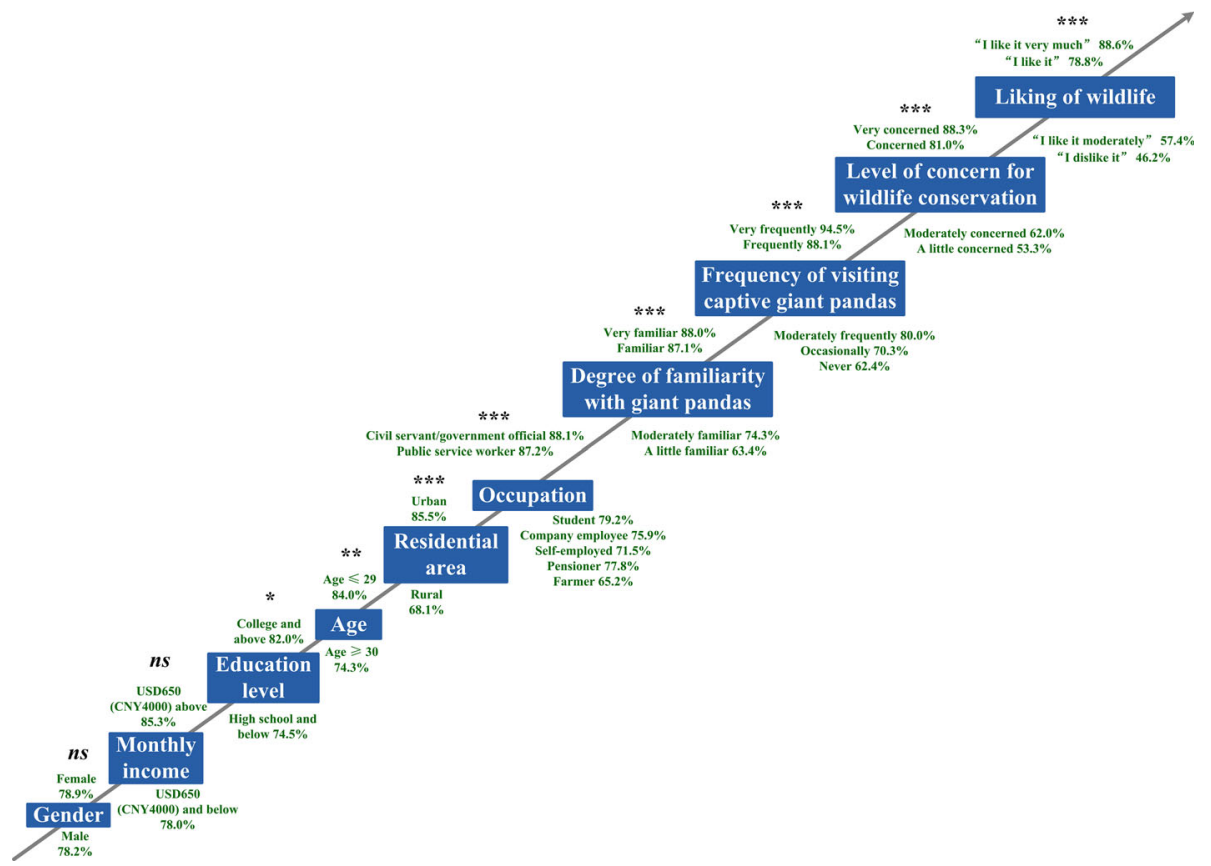

Fig. 2 Logistic regression analysis of willingness-to-pay towards the Giant Panda Reintroduction Project. Percentage value indicates the percentage of people who were willing to pay. ns no significance, $* * * P<0.001, * * P<0.01, * P<0.05$ (two-tailed)

numbers in the wild" (49.7 \%); "because I have a sense of social responsibility" (34.6\%); "the reintroduction of giant pandas will help to promote local development" (32.7\%); and "to increase opportunities to watch the pandas" $(27.9 \%)$. For the preferred payment 
method(s), there was a significant difference among the eight payment methods $\left(\chi^{2}=198.282, d f=7, P=0.000\right)$. The three most preferred payment methods by cash were: "donation to a Wildlife Conservation Fund" (such as China Wildlife Conservation Association; $26.8 \%$ of willing respondents); "tickets to visit Panda Houses in zoos" (16.0\%); and "donation to the relevant agencies (Wolong Panda Club) of China Conservation and Research Center for the Giant Panda" (14.7\%). Less than half of WTP respondents selected the remaining five kinds of non-cash payment methods: "donation of funds to the relevant institutes by bank transfer, remittances etc. (including online banking payments)" (9.8\%); "money obtained through the purchase of certain goods (such as giant panda souvenirs, etc.) and indirectly donated to the relevant institutes" (9.7\%); "by sending a cell phone text message to donate to the relevant institutes" (9.1\%); "in the form of a land-fill tax paid to the state" (7.6\%); and "through a third party payment platform (e.g. PayPal and Tenpay) that will donate funds to the relevant institutes" $(6.3 \%)$.

People who were unwilling to pay for the project stated $\left(\chi^{2}=51.088, d f=4\right.$, $P=0.000)$ : "I have a low income; it is difficult to pay other expenses" (31.3\%); "all costs should be funded by the state and not by individuals" (30.0\%); "I do not believe that the donated funds will be rationally or really used to protect the giant panda" (18.9\%); and "I am unwilling to invest money to participate in this public service, but prefer to help protect the giant panda in other ways (such as by volunteering)" (14.3\%). Only $5.5 \%$ of people said that they were unwilling to pay because they were not interested in the conservation of giant pandas.

\section{Discussion}

Here, we evaluated the public acceptance of a reintroduction program of the giant panda in Huaying city (Sichuan, Southwest China) to evaluate the potential for a human-wildlife conflict prior to the actual reintroduction. Public support for the GPRP is strong and broadbased. The positive attitude is associated with a high degree of concern about giant pandas obtained from various media. Giant pandas are considered to be charismatic animals: they not only have a high ecological value but also social and political functions (Du 2012). As Reading and Clark (1996) concluded, gaining support for charismatic species like bears is easier than for small, lesser-known species. Social, economic and ecological benefits to the local community are another way to increase support. For example, in Chile, strong support for the reintroduction of guanaco (Lama guanicoe) is due to guanaco as a symbol of social culture (Lindon and Root-Bernstein 2015). In Oman, many people are employed by the captive-born Arabian oryx (Oryx leucoryx) reintroduction program and the program is widely accepted by the local community (Fitter 1984; Price 1986). In Scotland, the public are generally positive about wolf (Canis lupus) reintroductions because the species plays an important role in maintaining ecological functions in the ecosystem (Nilsen et al. 2007).

The GPRP will have remarkable impacts on the local economy and development. First, the 'celebrity effect' of the giant panda will improve the popularity of Huaying. For example, Huaying, a small county in the past, has become a famous county-level city not only in Sichuan but also around China after the state and provincial television reported the news of GPRP. Second, giant pandas will attract tourists and large potential investment (financial and human resources) will provide many job opportunities for local people thereby promoting economic development and increasing fiscal revenue. A wild-training 
base was built and a pair of panda was moved in on August 25, 2014. This pair of panda's coming has greatly promoted the Tour Festival of Huaying in 2015 (Huaying On-line 2015). Third, as it is a strong symbol and representative for the conservation of nature, the giant panda is likely to arouse public awareness of environmental protection and improve the ecological environment. Inevitably, the GPRP may damage the interests of villagers neighboring the target panda reintroduction area in Huaying Mountain. For instance, it will be a prerequisite for the local government to establish a reserve prior to implementing the GPRP. Some villagers may have to return their farmland to recover forestry, and some villagers living inside the target panda reintroduction area may have to move out to other places albeit they can get some compensation by doing so. Nonetheless, the positive effects of GPRP outweigh any negatives, and local residents earnestly hope that giant pandas will be reintroduced. Some villagers losing farm land can act as reserve patrollers or even staff at the reserve.

In our study, residential area, occupation and education level affected attitudes and WTP towards the GPRP. First, many studies have shown that rural residents tend to have more negative attitudes towards reintroduction programs than urban residents (Ericsson and Heberlein 2003; Morzillo et al. 2010; Nilsen et al. 2007; Williams et al. 2002; Yen et al. 2015). Kellert (1994) postulated that being rural tended to predispose one to more negative attitudes toward bears because these individuals are more connected to land-use problems. Our results support this interpretation that rural residents were less supportive of the GPRP than urban residents because some rural residents worry that their land will be expropriated by the government as a result of the GPRP. Second, people working in government agencies, state-owned companies and public services have a more positive attitude and are more willing to pay than people in other professions. This is likely because those people working government agencies and public services have a greater job security and may get more money from tourism than other occupations. Thus, it is understandable that those people usually have a greater awareness of conservation ( $\mathrm{Du}$ et al. 2010; Mahanta and Das 2013). The lowest level of support for the GPRP occurred amongst farmers and pensioners, probably because farmers will be directly and negatively affected by the reintroduction by being forbidden in mining, bamboo and bamboo shoot collecting etc. in the targeted GPRP area (Naughton-Treves et al. 2003; Williams et al. 2002). For the pensioners, however, we thought their lower support were highly related to their low and fix income and the increasing price of food and costs for medicine and hospitalization. Third, people with higher levels of education had more positive attitudes because increased education often brings a greater awareness of wildlife and environment (Kellert 1984; Masud and Kari 2015; Zhou et al. 2009). Interestingly, we found no relationship between age and support for the GPRP, yet young people are more willing to pay for the project than older people. This is possibly because young people may also be able to earn more or they may feel that they can earn more. The older people, however, may be more on a fixed income. More than three quarters of the local people had a positive attitude toward the GPRP, but not everyone was willing to pay for the project. The WTP associated with age is probably a cohort effect (Bowman et al. 2004; Kellert 1994; Williams et al. 2002) as younger age groups may be more influenced by communications about donating to endangered species recovery, especially charismatic megafauna.

Evaluations of nature and conservation that are utilitarian, intrinsic or esthetic are influenced by affective (emotional) considerations or by rational (also called 'cognitive') considerations (Crites et al. 1994; Edwards 1990). Human affections influence virtually all aspects of cognition, such as attention (Ohman 2009), perception (Dolan 2002) and motivation (Izard 2009). Personal feelings are considered important factors in evaluating 
the likelihood of public acceptance to reintroduction programs (Hermann and Menzel 2013; Tosi et al. 2015). We found that the more people like wildlife, the more concerned they are about wildlife conservation, and the more familiar they are with giant pandas the more supportive they are of the project. People who frequently visited captive giant pandas had a more positive attitude than those who occasionally or never visited zoos or giant panda breeding centers. This suggests that a subjective bias with emotional experience can influence attitudes, which are more central in cognitive systems (Ericsson and Heberlein 2003; Petty et al. 1992; Seamon 1984).

Despite members of the local community strongly supporting the GPRP and most people being willing to pay for the program, more than $20 \%$ respondent were unwilling to pay for the GPRP (Fig. 1). Some of them possibly cannot afford it, while others thought it was not their own but the state's responsibility to support the project. Nonetheless, about one in ten preferred to help in other ways. In addition, doubts about the appropriate use of donated funds significantly prevented some respondents from donating to the project. This indicates a crisis of confidence and creditability. Negative phenomena in a society, such as misusing and corruption, can easily impair the public's decision to donate. A young Chinese woman's blog about the funding using of Red Cross Society of China in 2011 enraged the public and put the society into an unprecedented crisis of trust (China Daily 2011). Similarly, the act of misusing charity funds by American Red Cross has infuriated the public and caused some protests (CBS News 2014). Our findings suggest that governmental and non-governmental organizations for environmental protection should increase accountability and transparency by frequently releasing information about their use of the donated funds. In addition, the managing institutions, either the state or a nongovernment organization, need to do a better job explaining why the funds are needed. Last, some additional opportunities should be created for members of the public to engage in works or activities concerning with giant pandas via increased contact at breeding facilities in order to maintain high enthusiasm amongst current supporters of the program and foster support amongst new groups of people.

Acknowledgments Thanks to staff at the Huaying Forestry Bureau for their assistance in distributing and collecting questionnaires. We appreciated insightful comments and suggestions from two anonymous reviewers.

Funding This work was supported by the National Natural Science Foundation of China (NSFC, Grant 31472009), National Key Technology R \& D Program (Grant 2012BAC01B06), The International Collaborative Project on the Conservation for the Giant Panda to D Liu (Grant Beijing 2010-2002) and R Wei (Grant WH0630), and National Key Program of Research and Development, Ministry of Science and Technology of the P. R. China (2016YFC0503200).

\section{Compliance of ethical standards}

Conflict of interest The authors declare that they have no conflict of interest.

Open Access This article is distributed under the terms of the Creative Commons Attribution 4.0 International License (http://creativecommons.org/licenses/by/4.0/), which permits unrestricted use, distribution, and reproduction in any medium, provided you give appropriate credit to the original author(s) and the source, provide a link to the Creative Commons license, and indicate if changes were made. 


\section{References}

Arrow K, Solow R, Portney PR et al (1993) Report of the NOAA panel on contingent valuation. Fed Regist 58:4601-4614

Arts K, Fischer A, Wal RVD (2012) Common stories of reintroduction: a discourse analysis of documents supporting animal reintroductions to Scotland. Land Use Policy 29:911-920

Bangs EE, Fritts SH (1996) Reintroducing the gray wolf to central Idaho and Yellowstone National Park. Wildl Soc Bull 24:402-413

Bar-David S, Saltz D, Dayan T et al (2005) Demographic models and reality in reintroductions: persian fallow deer in Israel. Conserv Biol 19:131-138

Bowman JL, Leopold BD, Vilella FJ, Gill DA (2004) A spatially explicit model, derived from demographic variables, to predict attitudes toward black bear restoration. J Wildl Manage 68:223-232

Bruskotter JT, Toman E, Enzler SA, Schmidt RH (2010) Are gray wolves endangered in the northern Rocky Mountains? A role for social science in listing determinations. Bioscience 60:941-948

Campbell MO, Alvarado MET (2011) Public perceptions of jaguars Panthera onca, pumas Puma concolor and coyotes Canis latrans in El Salvador. Area 43:250-256

Caruso F, Perez IJ (2013) Tourism, local pride, and attitudes towards the reintroduction of a large predator, the jaguar Panthera onca in Corrientes, Argentina. Endang Species Res 21:263-272

CBS news (2014) http://www.cbsnews.com/news/red-cross-accused-of-misusing-funds-during-hurricanesisaac-and-sandy/. Accessed 17th Aug 2016

China Daily (2011) http://www.chinadaily.com.cn/opinion/2011-07/15/content_12912148.htm. Accessed 17th Aug 2016

Chu C, Long Z (1983) The vicissitudes of the giant panda. Acta Zool Sinica 29:93-104

Cohn JP (1993) The flight of the California condor. Bioscience 43:206-209

Crites SL, Fabrigar LR, Petty RE (1994) Measuring the affective and cognitive properties of attitudes: conceptual and methodological issues. Pers Soc Psychol Bull 20:619-634

Davies HT, du Toit JT (2004) Anthropogenic factors affecting wild dog Lycaon pictus reintroductions: a case study in Zimbabwe. Oryx 38:32-39

Decker SE, Bath AJ, Simms A et al (2010) The return of the king or bringing snails to the garden? The human dimensions of a proposed restoration of European bison (Bison bonasus) in Germany. Restor Ecol 18:41-51

Dolan RJ (2002) Emotion, cognition, and behavior. Science 298:1191-1194

Du WQ (2012) On the giant panda and its social value. J Sichuan Forest Explore Des 1:1-10

Du H, Gan F, Wei QW et al (2010) Non-use value assessment of Chinese Sturgeon Nature Reserve of Yangtze River in Yichang, Hubei Province based on the contingent valuation method. Sichuan J of Zool 29:933-937

Edwards K (1990) The interplay of affect and cognition in attitude formation and change. J Pers Soc Psychol 59:202-216

Ericsson G, Heberlein TA (2003) Attitudes of hunters, locals, and the general public in Sweden now that the wolves are back. Biol Conserv 111:149-159

Fischer J, Lindenmayer DB (2000) An assessment of the published results of animal relocations. Biol Conserv 96:1-11

Fitter R (1984) Operation Oryx-the success continues. Oryx 18:136-137

Fritts SH, Bangs EE, Fontaine JA et al (1997) Planning and implementing a reintroduction of wolves to Yellowstone National Park and central Idaho. Restor Ecol 5:7-27

Han SY, Lee CK, Mjelde JW, Kim TK (2010) Choice-experiment valuation of management alternatives for reintroduction of the endangered mountain goral in Woraksan National Park, South Korea. Scand J Forest Res 25:534-543

Heberlein TA (2012) Navigating environmental attitudes. Conserv Biol 26:583-585

Hermann N, Menzel S (2013) Predicting the intention to support the return of wolves: a quantitative study with teenagers. J Environ Psychol 36:153-161

Hermann N, Voss C, Menzel S (2013) Wildlife value orientations as predicting factors in support of reintroducing bison and of wolves migrating to Germany. J Nat Conserv 21:125-132

Hook RA, Robinson WL (1982) Attitudes of Michigan citizens toward predators. In: Hanington FH, Paquet PC (eds) Wolves of the world: perspectives of behavior, ecology, and conservation. Noyes Publications, Park Ridge, pp 382-394

Hu JC, Wang RF, Xiong ZY (1995) A fossil of the giant panda discovered in the Huaying Mountains. J Sichuan Teach Coll (Nat Sci) 16:1-5

Hu XS, Hong W, Wu CZ, Qiu RZ (2013) Improvement of key techniques of contingent valuation method in estimating environmental resource value. Chin J Ecol 32:3101-3108 
Huaying On-line (2015) http://www.huaying.ccoo.cn/news/local/3748391.html. Accessed 17th, Aug 2016 IUCN/SSC (2013) Guidelines for Reintroductions and Other Conservation Translocations. Version 1.0. IUCN Species Survival Commission, Gland, Switzerland

Izard CE (2009) Emotion theory and research: highlights, unanswered questions, and emerging issues. Annu Rev Psychol 60:1-25

Jacobs MH, Vaske JJ, Dubois S, Fehres P (2014) More than fear: role of emotions in acceptability of lethal control of wolves. Eur J Wildl Res 60:589-598

Kellert SR (1984) American attitudes toward and knowledge of animals: An update. In: Fox MW, Mickley LD (eds) Advances in animal welfare science. The Humane Society of the United States, Washington, D.C., pp 177-213

Kellert SR (1994) Public attitudes toward bears and their conservation. Bears 9:43-50

Kellert SR, Berry JK (1980) Knowledge, affection and basic attitudes toward animals in american society. Phase III. Fish and Wildlife Service, Washington, D.C.

Kleiman DG (1989) Reintroduction of captive mammals for conservation. Bioscience 39:152-161

Kleiman DG, Stanley PMR, Beck BB (1994) Criteria for reintroductions. In: Olney PJS, Mace GM, Feistner ATC (eds) Creatire conservation: interactive management of wild and captive animals. Chapman and Hall Press, New York, pp 287-303

Knegtering E, Hendrickx L, van der Windt HJ, Uiterkamp AJMS (2002) Effects of species' characteristics on nongovernmental organizations' attitudes toward species conservation policy. Environ Behav 34:378-400

Kontoleon A, Swanson T (2003) The willingness to pay for property rights for the giant panda: can a charismatic species be an instrument for nature conservation. Land Econ 79:483-499

Kriström B (1997) Spike models in contingent valuation. Am J Agric Econ 79:1013-1023

Lee Y, Harrison JL, Eisenberg C, Lee B (2012) Modeling biodiversity benefits and external costs from a keystone predator reintroduction policy. J Mt Sci 9:385-394

Li S, Wang DJ, Gu XD, McShea WJ (2010) Beyond pandas, the need for a standardized monitoring protocol for large mammals in Chinese nature reserves. Biodivers Conserv 19:3195-3206

Lindon A, Root-Bernstein M (2015) Phoenix flagships: conservation values and guanaco reintroduction in an anthropogenic landscape. Ambio 44:458-471

Lindsey PA, du Toit JT, Mills MGL (2005) Attitudes of ranchers towards African wild dogs Lycaon pictus: conservation implications on private land. Biol Conserv 125:113-121

Loucks CJ, Lü Z, Dinerstein E et al (2001) Giant pandas in a changing landscape. Science 294:1465

MacMillan D, Hanley N, Lienhoop N (2006) Contingent valuation: environmental polling or preference engine. Ecol Econ 60:299-307

Mahanta R, Das D (2013) Attitudes towards biodiversity conservation of forests dwellers and encroachers: a case study of Assam in Northeast India. Small-scale For 12:307-319

Masud MM, Kari FB (2015) Community attitudes towards environmental conservation behaviour: an empirical investigation within MPAs, Malaysia. Mar Policy 52:138-144

Mayer FS, Frantz CM (2004) The connectedness to nature scale: a measure of individuals' feeling in community with nature. J Environ Psychol 24:503-515

Mitchell RC, Carson RT (1989) Using surveys to value public goods: the contingent valuation method. Resources for the Future Press, Washington, D.C.

Morzillo AT, Mertig AG, Hollister JW et al (2010) Socioeconomic factors affecting local support for black bear recovery strategies. Environ Manag 45:1299-1311

Naughton-Treves L, Grossberg R, Treves A (2003) Paying for tolerance: rural citizens' attitudes toward wolf depredation and compensation. Conserv Biol 17:1500-1511

Nilsen EB, Milner-Gulland EJ, Schofield L et al (2007) Wolf reintroduction to Scotland: public attitudes and consequences for red deer management. P Roy Soc B 274:995-1002

Nisbet EK, Zelenski JM, Murphy SA (2009) The nature relatedness scale linking individuals' connection with nature to environmental concern and behavior. Environ Behav 41:715-740

Nolet BA, Rosell F (1998) Comeback of the beaver Castor fiber: an overview of old and new conservation problems. Biol Conserv 83:165-173

Nuva R, Shamsudin MN, Radam A, Shuib A (2009) Willingness to pay towards the conservation of ecotourism resources at Gunung Gede Pangrango National Park, West Java, Indonesia. J Sustain Dev 2:173-186

Ohman A (2009) Of snakes and faces: an evolutionary perspective on the psychology of fear. Scand J Psychol 50:543-552

O'Rourke E (2014) The reintroduction of the white-tailed sea eagle to Ireland: people and wildlife. Land Use Policy 38:129-137 
Osborne PE, Seddon PJ (2012) Selecting suitable habitats for reintroductions: variation, change and the role of species distribution modeling. In: Ewen JG, Armstrong DP, Parker KA, Seddon PJ (eds) Reintroduction biology: integrating science and management. Wiley-Blackwell, Oxford, pp 73-104

Osterberg P, Samphanthamit P, Maprang O et al (2015) Gibbon (Hylobates lar) reintroduction success in Phuket, Thailand, and its conservation benefits. Am J Primatol 77:492-501

Pan DS, Wang HJ, Li YH et al (2010) Survey of public awareness on wildlife conservation in communities around Daxiagu Nature Reserve, Guangdong. Chin J Wildl 31:218-220

Perkins HE (2010) Measuring love and care for nature. J Environ Psychol 30:455-463

Petty RE, Unnava RH, Strathman AJ (1992) Theories of attitude change. In: Robertson TS, Kassarjian HH (eds) Handbook of Consumer Behavior. Prentice Hall, Englewood Cliffs, pp 241-268

Price MRS (1986) The reintroduction of the Arabian oryx (Oryx leucoryx) into Oman. Int Zoo Yearbook 24:179-188

Reading RP, Clark TW (1996) Carnivore reintroductions: an interdisciplinary examination. In: Gittleman JL (ed) Carnivore Behavior, Ecology, and Evolution, vol 2. Cornell University Press, New York, pp 296-336

Reading RP, Kellert SR (1993) Attitudes toward a proposed reintroduction of black-footed ferrets (Mustela nigripes). Conserv Biol 7:569-580

Reading RP, Clark TW, Kellert SR (1991) Toward an endangered species reintroduction paradigm. Endang Species Update 8:1-4

Reiser B, Shechter M (1999) Incorporating zero values in the economic valuation of environmental program benefits. Environmetrics 10:87-101

Richardson L, Loomis J (2009) The total economic value of threatened, endangered and rare species: an updated meta-analysis. Ecol Econ 68:1535-1548

Scheaffer RL, Mendenhall W, Ott RL, Gerow K (2011) Elementary Survey Sampling, 7th edn. Duxbury Press, New York

Seamon D (1984) Emotional experience of the environment. Am Behav Sci 27:757-770

Seddon PJ, Strauss WM, Innes J (2012) Animal translocations: what are they and why do we do them? In: Ewen JG, Armstrong DP, Parker KA, Seddon PJ (eds) Reintroduction biology: integrating science and management. Wiley-Blackwell, Oxford, pp 1-32

State Forestry Administration (2014) The 4rd national survey report on Giant Panda in China. Science Press, Beijing

Su T, Chen M, Zhang ED et al (2008) Social value of reintroducing Chinese water deer (Hydropotes inermis) into Shanghai. Sichuan J Zool 27:142-144

Tisdell C, Swarna Nantha H, Wilson C (2007) Endangerment and likeability of wildlife species: how important are they for payments proposed for conservation. Ecol Econ 60:627-633

Tosi G, Chirichella R, Zibordi F et al (2015) Brown bear reintroduction in the Southern Alps: to what extent are expectations being met. J Nat Conserv 26:9-19

Turpie JK (2003) The existence value of biodiversity in South Africa: how interest, experience, knowledge, income and perceived level of threat influence local willingness to pay. Ecol Econ 46:199-216

Voltaire L, Pirrone C, Bailly D (2013) Dealing with preference uncertainty in contingent willingness to pay for a nature protection program: a new approach. Ecol Econ 88:76-85

Wei FW, Hu YB, Zhu LF et al (2012) Black and white and read all over: the past, present and future of giant panda genetics. Mol Ecol 21:5660-5674

Williams CK, Ericsson G, Heberlein TA (2002) A quantitative summary of attitudes toward wolves and their reintroduction (1972-2000). Wildl Soc Bull 30:575-584

Wilson CJ (2004) Could we live with reintroduced large carnivores in the UK. Mamm Rev 34:211-232

Worthington T, Tisdale J, Kemp P et al (2010) Public and stakeholder attitudes to the reintroduction of the burbot, Lota lota. Fisheries Manag Ecol 17:465-472

Yen SC, Chen KH, Wang Y, Wang CP (2015) Residents' attitudes toward reintroduced sika deer in Kenting National Park. Taiwan Wildl Bio 21:220-226

You WB, He DJ, Hong W et al (2014) The non-use value of heritage resources in Wuyishan scenery district using the contingent valuation method. Resour Sci 36:1880-1888

Zhang WZ, Goodale E, Chen J (2014a) How contact with nature affects children's biophilia, biophobia and conservation attitude in China. Biol Conserv 177:109-116

Zhang MC, Huang JY, Huang Y et al (2014b) Preliminary survey for the giant panda reintroduce to Huayingshan. Sichuan J Zool 33:376-380

Zhou XH, Ma JZ, Zhang W, Wang Q (2009) Evaluating the economic value of endangered species conservation with contigent method and its reliability analysis - a case study on the willingness to pay of the citizens in Harbin on Amur. J Nat Resour 24:276-285 